\title{
The Impact of University Level Sports Education on Social Media Addiction
}

\section{Bilal Okudan ${ }^{1}$ \\ Ömür Fatih Karakullukçu²}

Adnan Menderes Universtiy, Sports Science Faculty, Turkey. Email:bilalokudan@gmail.com

${ }^{2}$ Turkey School Sports Federation of President, Ankara, Turkey.

Email:omurkarakullukcu@gmail.com

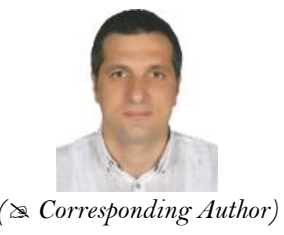

Abstract

The aim of this study is to analyse the effects of university level sport education on social media addiction. For this purpose, social media addiction scales filled in by 320 students from the faculty of Sports Sciences and 333 students from the faculty of Education were evaluated. T-test, one-way variance analysis (ANOVA) and LSD test were used in statistical procedures. In the study, occupation, mood modification, relapse and conflict scores were found to be statistically significantly different in terms of gender $(\mathrm{p}<0.05$ and $\mathrm{p}<0.001)$. Statistically significant difference was also found in social media addiction total score in terms of the year of study $(p<0.05$ and $\mathrm{p}<0.001)$. Occupation, mood modification, relapse, conflict and social media addiction scale scores of faculty of sport sciences students were found to be lower than the scores of education faculty students $(\mathrm{p}<0.001)$. Conclusion: It was found that social media addiction level of students receiving sport education was lower when compared with students who were not receiving sport education and it was concluded that sport education could be effective in decreasing social media addiction. It can be recommended to provide opportunities to receive sport education and to do sport to university students who are not receiving sport education.

Keywords: University, Education, Student, Social media, Addiction, Sport.

Citation | Bilal Okudan; Ömür Fatih Karakullukçu (2021). The Impact of University Level Sports Education on Social Media Addiction. Asian Journal of Education and Training, 7(1): 7-12. History:

Received: 4 November 2020

Revised: 30 November 2020

Accepted: 21 December 2020

Published: 6 January 2021

Licensed: This work is licensed under a Creative Commons Attribution 3.0 License $($ (c) $)$ EY

Publisher: Asian Online Journal Publishing Group
Acknowledgement: Both authors contributed to the conception and design of the study.

Funding: This study received no specific financial support

Competing Interests: The authors declare that they have no conflict of interests.

Transparency: The authors confirm that the manuscript is an honest, accurate, and transparent account of the study was reported; that no vital features of the study have been omitted; and that any discrepancies from the study as planned have been explained.

Ethical: This study follows all ethical practices during writing.

\section{Contents}

1. Introduction 8

2. Method

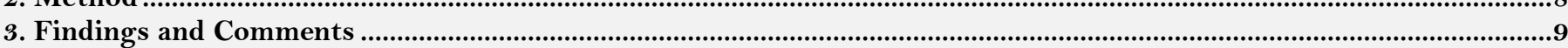

4. Results and Discussion

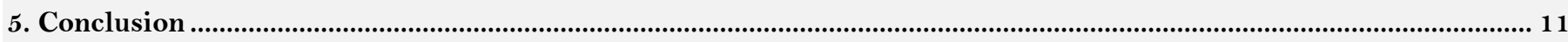

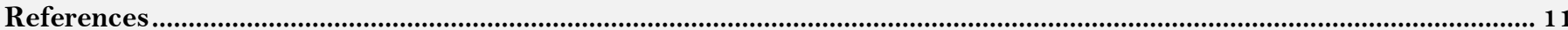




\section{Contribution of this paper to the literature}

It is thought that taking sports training at the university level contributes to being conscious about the use of social media. This study will contribute to the sports literature on the social media addiction of students who receive sports education at university level.

\section{Introduction}

Social networks is a type of online activity with an emphasis on e-mail/messaging and there are a large number of social media applications that can serve these activities (Tutgun-Ünal, 2015). Social media has a large effect especially on life and daily routine as an important social platform to develop the connections with friends circle and the relationships with new friends (Tulu, 2017). The services and the technical infrastructure provided to individuals by social media may cause addiction by causing their problematic use (Aktan, 2018). Studies have shown that young people use social media to a great extent (Akyazı \& Tutgun-Ünal, 2013; Köroğlu \& Tutgun, 2013; Vural \& Bat, 2010). It has been stated that many of these uses are extreme (Andreassen, 2012; Cam \& Isbulan, 2012; Hazar, 2011). Individuals meet some of their needs by using the mass media and relax psychologically and through the satisfaction they get from the media, they relax psychologically and their tension is reduced. In addition to physiological needs, mass media also emerges in terms of meeting psychological and cultural needs (Bayram, 2008). Social networking sites, one of the most important components of social media, are seen as virtual communities in which users can create personal profiles, interact with friends and meet other people based on common interests (Kuss \& Griffiths, 2011). These virtual communities occur in networks, especially where young people come together (Casale \& Fioravanti, 2018). While social media enables individuals to communicate, it also enables them to come together and organize for a specific purpose outside specific places (Diker \& Uçar, 2016).

Social media addiction is a kind of internet addiction. A large number of studies have shown that electronic media use and social media addiction have a negative effect on daily life activities (Andreassen, 2012); (Suganuma et al., 2011). Individuals continue their social relationships in social media environment when they are not in the same environment. This is the reason why social networks are used so intensively (Tutgun-Ünal, 2015). Tablets, mobile phones and easy access of employees to the internet at the work place are seen as an important factor in social media use reaching a level that causes the society to worry (Şahin \& Yağcl, 2017). People who spend a lot of time on social media have a greater desire to know immediately about virtual communication and something that may cause virtual problem (Sahin., 2018). It has been suggested that overuse of new technology (especially online social networks) can cause a potential mental health problem, loneliness and addiction in young people (Echeburua \& De Corral, 2010; Stankovska, Angelkovska, \& Grncarovska, 2016). Social media addicts show obsessed behaviours and cannot control the use of these devices (Hwang, 2017). While using social media, athletes are faced with the obligation to comply with the patterns determined by the society. The use of social media, which will be carried out in violation of the social structure, will create the risk of reducing the support of the athlete from the society and the value of the club (Ünver \& Köse, 2020). A large number of studies have shown that social network use can cause negative consequences such as decreased real-life groups, worse academic performance and relationship problems (Kuss \& Griffiths, 2011). Social media addiction is a psychological problem that causes problems like occupation, mood modification, relapse and conflict in many areas of daily life such as private, work/academic, social areas by developing with cognitive, affective and behavioural processes (Tutgun-Ünal, 2015). Internet addiction can be seen in different ways. One of these is computer addiction including computer games; another one is internet focused addiction, while others are online shopping or gambling, online pornography, social networking sites addiction. Social networking site addiction, which constitutes an important part of social media, is the newest addiction type (Kuss \& Griffiths, 2011). Social media addiction has been defined as the state of being overly occupied with social media channels, having an intense desire to stay connected to these channels all the time and spending too much time in these channels that will harm other activities in social life, student/business life, interpersonal communication and mental state (Andreassen., Torsheim, \& Pallesen, 2014). Social media addiction, which does not have a precise definition, is expressed as a subfield of internet addiction (Eijnden, Lemmens, \& Valkenburg, 2016; Longstreet \& Brooks, 2017). Or the addicted use of social media (such as Facebook, Snapchat, WhatsApp, and Twitter) can be seen as a specific form of technological addiction (Turel, Brevers, \& Bechara, 2018). With social media, users create content independent from time, place and control and distribute and reproduce the content they produce (Aktan, 2018). Social media, which allows people to show their interests through their personal pages, to interact with others through various applications, to obtain information, to make friends, to share photos and images with other people and/or to present data to people about their personal information, can create addiction when it is used unconsciously and excessively (Balcı \& Baloglu, 2018).

\section{Method}

\subsection{Participants}

The participants were students who attended university in different departments of Ondokuz Mayıs University and who were at the same time social media users. The questionnaires filled in by 300 male and 280 female students were evaluated. 275 of the students were students in the faculty of Sport Sciences, while 323 were students in the faculty of Education who were not receiving sport education.

\subsection{Measurement Instrument}

Social Media Addiction Scale (SMAS): Social Media Addiction Scale (SMAS) is a measurement instrument developed to measure the social media addiction levels of university students. After all validity and reliability studies, the scale included 41 items. The subscales of the scale are occupation including items 1, 2, 3, 4, 5, 6, 7, 8, 9, 10, 11 and 12; mood modification including items 13,14, 15, 16 and 17; relapse including items 18, 19, 20, 21 and 22; and conflict including items 23, 24, 25, 26, 27, 28, 29, 30, 31, 32, 33, 34, 35, 36, 37, 38., 39, 40 and 41. The items in the scale were scored as " $1=$ Never, $2=$ Rarely, $3=$ Sometimes, $4=$ Often, $5=$ Always". The highest score one can 
take from the social media addiction scale is 205, while the lowest score one can get is 41 (Tutgun-Ünal, 2015). Scores between 41 and 73 show that the individual does not have addiction. Scores between 74 and 106 show the presence of addiction. Scores between 107 and 139 show moderate addiction, while scores between 140 and 172 show high addiction and scores between 173 and 205 show very high addiction (Aktan, 2018).

\subsection{Statistical Analysis}

SPSS 25, O0 program was used for statistical analysis. Kolmogorov-Smirnov test was conducted to find out whether the data were normally distributed and the data were found to be normally distributed. Independent samples t-test was used to compare paired groups, while one way ANOVA and LSD test were used to compare more than two groups.

\section{Findings and Comments}

Anthropometric characteristics of the participants are given in Table 1. In Table 2, social media addiction is compared by gender. In Table 3, the comparison of social media addiction according to the year of education is given. In Table 4, the comparison of social media addiction according to the sports education status is given.

Table-1. Comparison of age, height and weigh in terms of gender.

\begin{tabular}{c|c|c|c|c|c}
\multicolumn{7}{c}{ Table-1. Comparison of age, height and weigh in terms of gender. } \\
\hline Parameter & Gender & N & Mean & St. deviation & t-test \\
\hline \multirow{2}{*}{ Age $($ years) } & Male & 326 & 21,55 & 2,31 & \multirow{2}{*}{0,94} \\
& Female & 305 & 21,40 & 1,78 & \\
\hline \multirow{2}{*}{ Height $(\mathrm{cm})$} & Male & 326 & 175,78 & 4,99 & \multirow{2}{*}{$13,05^{* *}$} \\
& Female & 305 & 170,00 & 6,11 & \\
\hline Weight $(\mathrm{kg})$ & Male & 326 & 73,26 & 7,44 & \multirow{2}{*}{$17,46^{* *}$} \\
\cline { 2 - 5 } & Female & 305 & 63,13 & 7,11 & \\
\hline Note: ${ }^{* *} \mathrm{p}<0.001$. & & &
\end{tabular}

The average age of students in this study is 21.40 years for females and 21.55 years for males. While the ages of the participants are similar to each other, their height and body weights are statistically different $(p<0.001)$.

\begin{tabular}{|c|c|c|c|c|c|}
\hline Subscales & Gender & $\mathbf{N}$ & Mean & St. deviation & t-test \\
\hline \multirow[t]{2}{*}{ Occupation } & Male & 339 & 32,92 & 9,91 & \multirow[t]{2}{*}{$4,37 * *$} \\
\hline & Female & 314 & 29,57 & 9,66 & \\
\hline \multirow{2}{*}{$\begin{array}{l}\text { Mood } \\
\text { modification }\end{array}$} & Male & 339 & 14,35 & 4,61 & \multirow[t]{2}{*}{$4,78 * *$} \\
\hline & Female & 314 & 12,65 & 4,47 & \\
\hline \multirow[t]{2}{*}{ Relapse } & Male & 339 & 14,19 & 4,50 & \multirow[t]{2}{*}{$4,15^{* *}$} \\
\hline & Female & 314 & 12,72 & 4,55 & \\
\hline \multirow[t]{2}{*}{ Conflict } & Male & 339 & 53,22 & 15,31 & \multirow[t]{2}{*}{$2,83^{*}$} \\
\hline & Female & 314 & 49,73 & 16,14 & \\
\hline \multirow[t]{2}{*}{ Total scale } & Male & 339 & 114,68 & 31,49 & \multirow[t]{2}{*}{$4,01 * *$} \\
\hline & Female & 314 & 104,67 & 32,19 & \\
\hline
\end{tabular}

Social media addiction sub-dimensions and total scale scores are significantly different according to gender $(\mathrm{p}$ $<0.05$ and $\mathrm{p}<0.001)$.

Table-3. Comparison of social media addiction scores in terms of year of study.

\begin{tabular}{|c|c|c|c|c|c|}
\hline Subscales & Year of study & $\bar{n}$ & Mean & St. Deviation & $\mathbf{F}$ \\
\hline \multirow[t]{5}{*}{ Occupation } & 1 & 123 & 28,63 & 11,04 & \multirow{5}{*}{$\begin{array}{l}6,51^{* * *} \\
1,2<3,4\end{array}$} \\
\hline & 2 & 186 & 30,28 & 9,17 & \\
\hline & 3 & 166 & 32,74 & 10,19 & \\
\hline & 4 & 178 & 32,91 & 9,15 & \\
\hline & Total & 653 & 31,31 & 9,93 & \\
\hline \multirow{5}{*}{$\begin{array}{l}\text { Mood } \\
\text { modification }\end{array}$} & 1 & 123 & 12,71 & 5,40 & \multirow{5}{*}{$\begin{array}{c}2,96^{*} \\
1<4\end{array}$} \\
\hline & 2 & 186 & 13,43 & 4,25 & \\
\hline & 3 & 166 & 13,44 & 4,51 & \\
\hline & 4 & 178 & 14,29 & 4,43 & \\
\hline & Total & 653 & 13,53 & 4,62 & \\
\hline \multirow[t]{5}{*}{ Relapse } & 1 & 123 & 12,33 & 5,24 & \multirow{5}{*}{$\begin{array}{c}3,96^{*} \\
1<2,3,4\end{array}$} \\
\hline & 2 & 186 & 13,44 & 4,24 & \\
\hline & 3 & 166 & 13,70 & 4,42 & \\
\hline & 4 & 178 & 14,13 & 4,47 & \\
\hline & Total & 653 & 13,48 & 4,58 & \\
\hline \multirow[t]{5}{*}{ Conflict } & 1 & 123 & 47,20 & 17,89 & \multirow{5}{*}{$\begin{array}{c}4,63^{*} \\
1<2,3,4\end{array}$} \\
\hline & 2 & 186 & 51,45 & 14,91 & \\
\hline & 3 & 166 & 52,36 & 15,21 & \\
\hline & 4 & 178 & 53,89 & 15,22 & \\
\hline & Total & 653 & 51,54 & 15,80 & \\
\hline \multirow[t]{5}{*}{ Total scale } & 1 & 123 & 100,86 & 37,38 & \multirow{5}{*}{$\begin{array}{c}5,34 * * \\
1<2,3,4 \\
2<4\end{array}$} \\
\hline & 2 & 186 & 108,59 & 29,56 & \\
\hline & 3 & 166 & 112,23 & 31,37 & \\
\hline & 4 & 178 & 115,21 & 30,54 & \\
\hline & Total & 653 & 109,87 & 32,20 & \\
\hline
\end{tabular}

Note: $* \mathrm{p}<0.05$ and $* * \mathrm{p}<0.001$ 
A statistically significant difference was found in the scale sub-dimensions and the total scale score according to the year of education $(\mathrm{p}<0.05$ and $\mathrm{p}<0.001)$.

Table-4. Comparison of social media addiction scores in terms of faculty

\begin{tabular}{|c|c|c|c|c|c|}
\hline Subscales & Faculty & $\mathbf{N}$ & Mean & St. deviation & t-test \\
\hline \multirow[t]{2}{*}{ Occupation } & Sport Sciences & 320 & 29,98 & 9,42 & \multirow[t]{2}{*}{$-3,38^{* *}$} \\
\hline & Education & 333 & 32,59 & 10,24 & \\
\hline \multirow{2}{*}{$\begin{array}{c}\text { Mood } \\
\text { modification }\end{array}$} & Sport Sciences & 320 & 12,62 & 4,20 & \multirow[t]{2}{*}{$-5,04 * *$} \\
\hline & Education & 333 & 14,41 & 4,84 & \\
\hline \multirow[t]{2}{*}{ Relapse } & Sport Sciences & 320 & 12,43 & 4,24 & \multirow[t]{2}{*}{$-5,89^{* *}$} \\
\hline & Education & 333 & 14,49 & 4,68 & \\
\hline \multirow[t]{2}{*}{ Conflict } & Sport Sciences & 320 & 48,27 & 15,60 & \multirow[t]{2}{*}{$-5,30 * *$} \\
\hline & Education & 333 & 54,69 & 15,37 & \\
\hline \multirow[t]{2}{*}{ Total scale } & Sport Sciences & 320 & 103,30 & 30,89 & \multirow[t]{2}{*}{$-5,21 * *$} \\
\hline & Education & 333 & 116,18 & 32,21 & \\
\hline
\end{tabular}

Note: $* \mathrm{p}<0.05$ and $* * \mathrm{p}<0.001$

A statistically significant difference was found in the scale sub-dimensions and total score according to the sports education status $(\mathrm{p}<0.001)$.

\section{Results and Discussion}

In the present study, male participants were found to have a mean age of 21.55 and female participants were found to have a mean age of 21.40. Heights and weights of the male and female students in the study were found to be statistically significantly different $(\mathrm{p}<0.001)$.

In their studies, Cömlekci and Başol (2019); Balcı and Baloglu (2018); Demir and Kumcağ1z (2019); Baz (2018) and Aktan (2018) did not find statistically significant difference between female participants and male participants in terms of social media addiction. Tutgun-Ünal (2015) found that social media addiction levels of university students did not differ in terms of gender, while they were found to differ significantly in the subscales of occupation, mood modification and conflict. Tutgun-Ünal (2015) found difference in favour of women in occupation and mood modification subscales. According to Özdemir (2019) study, in comparing the social media addiction of university students by gender. Significant differences were found in the sub-dimensions of engagement, emotion regulation, conflict and social media total scores by gender. It is observed that the mean scores of the male participants are high.. Tutgun-Ünal (2015) found a difference in favour of men in conflict subscale. While Ciftci (2018) found difference in favour of men in relapse and conflict subscales, he did not report any differences in occupation, mood modification and social media addiction in terms of gender. In the present study, occupation, mood modification, relapse, conflict subscales and total scale scores were found to be statistically significantly different in terms of gender $(\mathrm{p}<0,05$ and $\mathrm{p}<0.001)$. The scores of male students were found to be significantly higher than those of female students. Male students are more occupied with social media than female students and they receive more emotional support from social media.

Aktan (2018) found the mean scores of social media addiction scale as 35.20 in occupation factor, as 13.17 in mood modification factor, as 13.43 in relapse factor, as 33.14 in conflict factor and as 97.71 in social media addiction total scale. In the present study, mean scores were found as 31.31 in occupation factor, as 13.53 in mood modification factor, as 13.48 in relapse factor, as 51.54 in conflict factor and as 109.87 in social media addiction total scale.

In their study, Balcı and Baloglu (2018) found the mean social media addiction level of the participants as 48.66. Ciftci (2018) found that the mean score of participants from social media addiction scale was 99.85. The conflict factor mean score and the social media addiction total mean score found in our study is higher than the aforementioned studies. In conflict factor, a score between 49 and 63 is considered as moderate addiction (Aktan, 2018). Sample differences and time difference may have affected this situation. It is thought that social media addiction increases each day. It has been found that individuals who neglect their spouses/family and friends and use the chat functions of social media experience conflict and at the same time their academic/professionals works are interrupted. This situation should not be ignored in university students and it should be accepted as a problem that should be solved. For example, in one study, Balcı and Baloglu (2018) found a positive significant correlation between social media addiction and depression. Scores between 74 and 106 indicate low addiction, while scores between 107 and 139 indicate moderate addiction (Aktan, 2018). In this study, the scores taken from social media addiction scale is 114.68 for men and 104.67 for women. According to this scoring, while male students have moderate level of media addiction, female students can be accepted as having low level of social media addiction.

According to the results of their studies, Tutgun-Ünal (2015) and Gürültü (2016) concluded that social media addiction scale scores did not differ significantly in terms of year of study. Ciftci (2018) reported differences in occupation, relapse, conflict and social media addiction. In this study, significant differences were found in social media addiction in terms of year of study $(\mathrm{p}<0.05$ and $\mathrm{p}<0.001)$. Occupation levels of first year students were found to be lower than third and fourth year students. It was found that third and fourth year students were more occupied with social media when compared with first and second year students. It can be said that these students cannot take their social media use under control and they repeatedly show this behaviour. It can also be said that third and fourth year students are more in conflict with social media and that they are negatively affected. It can be seen that third and fourth year students had higher addiction levels than first and second year students.

Baz (2018) did not find a significant difference in social media addiction total scores in terms of department. Tutgun-Ünal (2015) found that social media addiction levels of university students differed in terms of the faculty they were studying in. Aktan (2018) found a statistically significant difference between the program students were studying in and their occupation in social media. In this study, occupation, mood modification, relapse, conflict and total scale scores of sport faculty students were found to be lower than those of education faculty students $(p<0,001)$. In a study by Mammadzade, Yılmaz, Abiş, İmamoğlu, and Şahin (2020) it was seen that exercising had 
an effect on anger control and anger introversion, but had no effect on social media attitude. And in the study, it was suggested that young people who are not active in sports should do sports for anger control and control of anger in. In the study of Garashli, Yılmaz, Abiş, İmamoğlu, and Şahin (2020) it was concluded that team sports and individual sports have a similar effect on athletes' gender, sport type, body weight, age, psychological fragility and speech anxiety. Sports education and exercise can provide plus changes in personality traits, optimal performance, feelings and attitudes, and the quality of life of university students (Aslan \& Imamoglu, 2020; Koca, İmamoğlu, \& İmamoğlu, 2018; Yamak, İmamoğlu, \& Çebi, 2016).

Scores between 74 and 106 indicate low addiction, while scores between 107 and 139 indicate moderate addiction (Aktan, 2018). In this study, mean social addiction scale scores were 103, 30 for sport sciences faculty students and 116, 18 for education faculty students. These scores showed that sport sciences faculty students had low level of addiction, while education faculty students had moderate level of addiction. In many studies, it has been determined that sports increase the hope level and reduce the stress level in people (Deryahanoğlu, İmamoğlu, Yamaner, \& Uzun, 2016; İmamoğlu, 2020; İmamoğlu., Tutkun, \& Shen, 2018; Yamak \& İmamoğlu, 2019).

\section{Conclusion}

It was found that students receiving sport education had lower social media addiction than students who were not receiving sport education and it was concluded that sport education will be useful in decreasing social media addiction. It is recommended to provide opportunities to receive sport education and to do sport to university students who are not receiving sport education.

\section{References}

Aktan, E. (2018). Assessment of social media addiction levels of university students by numerous variables. Erciyes Communication Magazine, $5(4), 405-421$.

Akyazı, E., \& Tutgun-Ünal, A. (2013). The impact of high school students' intentions in the use of social media and the way of their adoption of social media on their success. Global Media Journal TR, 3(6), 1-24.

Andreassen, C. S. (2012). Development of a facebook addiction scale. Psychological Reports, 110(2), 501-517.

Andreassen., C. S., Torsheim, T., \& Pallesen, S. (2014). Predictors of use of social network sites at work-a specific type of cyberloafing. Journal of Computer-Mediated Communication, 19(4), 906-921.Available at: https://doi.org/10.1111/jcc4.12085.

Aslan, H., \& Imamoglu, O. (2020). Investigation of leisure strategies of sports educated students. Asian Journal of Education and Training, 6(3), 468-473.Available at: https://doi.org/10.20448/journal.522.2020.63.468.473.

Balcı, Ş., \& Baloglu, E. (2018). The relationship between social media addiction and depression: A field study on university Youth. Galatasaray University Journal of Communication(29), 209-234.

Bayram, F. (2008). Auses and gratifictions research on reading motivationse and gratifications ofnewspaper readers. Anadolu University Journal of Social Sciences, 8(1), 321-336.

Baz, F. Ç. (2018). Social media addiction: Working on college students. OPUS International Journal of Society Studies, 9(16), $276-295$.

Cam, E., \& Isbulan, O. (2012). A new addiction for teacher candidates: Social networks. Turkish Online Journal of Educational Technology, $11(3), 14-19$.

Casale, S., \& Fioravanti, G. (2018). Why narcissists are at risk for developing Facebook addiction: The need to be admired and the need to belong. Addictive behaviors, 76, 312-318.Available at: https://doi.org/10.1016/j.addbeh.2017.08.038.

Ciftci, H. (2018). Social media addiction in university students. MANAS Journal of Social Studies, 7(4), 417-434.

Cömlekci, M. F., \& Başol, O. (2019). Analysis of relationship between youths' social media usage motives and social media addiction. Celal Bayar University Journal of Social Sciences, 17(4), 173-188.

Demir, Y., \& Kumcağız, H. (2019). Investigation of university students' social media addiction in terms of different variables. Turkish Psychological Counseling and Guidance Journal, 9(52), 23-42.

Deryahanoğlu, G., İmamoğlu, O., Yamaner, F., \& Uzun, M. (2016). Anthropometric characteristics of sedentary women and comparison of their psychological states. Journal of Human Sciences, 13(3), 5257-5268.Available at: https://doi.org/10.14687/jhs.v13i3.4106.

Diker, Z., \& Uçar, M. (2016). A study on the reasons of social network use by the university students: The case of the Safranbolu Vocational School. Journal of Research in Education and Teaching, 1(5), 376-386.

Echeburua, E., \& De Corral, P. (2010). Addiction to New Technologies and to online social networking in young people: A newchallenge. Adicciones, 22, 91-95

Eijnden, R. V., Lemmens, J. S., \& Valkenburg, P. M. (2016). The social media disorder scale. Computers in Human Behavior, 61, 478487.Available at: https://doi.org/10.1016/j.chb.2016.03.038.

Garashli, J., Yılmaz, C., Abiş, S., İmamoğlu, O., \& Şahin, O. (2020). The effect of speech anxiety on psychological vulnerability in team and individual athletes. The Journal of International Social Research, 13(73), 1215-1219.

Gürültü, E. (2016). Investigation of the relationship between high school students' social media addiction and academic procrastination. (Unpublished Master's Thesis), Marmara University Institute of Educational Sciences, Istanbul.

Hazar, M. (2011). Social media addiction: A field study. Communication, Theory and Research Journal, 32, 151-175.

Hwang, H. S. (2017). The influence of personality traits on the Facebook addiction. KSII Transactions on Internet and Information Systems, $11(2), 1032-1042$.

İmamoğlu, O. (2020). Investigation of quality of life according to the exercise behavior change stages of women studying at university. European Journal of Physical Education and Sport Science, 6(3), 47-59.

İmamoğlu., O., Tutkun, E., \& Shen, G. (2018). Stress level and self relation in university students and coaches. Acta and Understanding, 4(1), $25-30$.

Koca, F., İmamoğlu, G., \& İmamoğlu, O. (2018). Sports status of high school students and investigation of personality characteristics by gender. The Journal of Academic Social Science, 6(80), $31-42$.

Köroğlu, O., \& Tutgun, Ü. A. (2013). The relationship between teacher candidates' adoption of social networks and their loneliness, New Media Congress, Kocaeli. Retrieved from http://aylinhoca.blogspot.com/p/ogretmen-adaylarinin-sosyal-aglari.html.

Kuss, D. J., \& Griffiths, M. D. (2011). Online social networking and addiction-a review of the psychological literature. International Journal of Environmental Research and Public Health, 8(9), 3528-3552.Available at: https://doi.org/10.3390/ijerph8093528.

Longstreet, P., \& Brooks, S. (2017). Life satisfaction: A key to managing internet \& social media addiction. Technology in Society, 50, 7377.Available at: https://doi.org/10.1016/j.techsoc.2017.05.003.

Mammadzade, M., Yılmaz, C., Abiş, S., İmamoğlu, O., \& Şahin, O. (2020). The effect of social media attitude of sports sciences students on their anger levels. The Journal of International Social Research, 13(73), 801-808.

Özdemir, Z. (2019). Social media addiction among university students. Journal of Beykoz Academy, 7(2), 91-105.

Şahin, C., \& Yağcı, M. (2017). Social media addiction scale - adult form: The reliability and validity study. Ahi Evran University Kırşehir Faculty of Education Journal (KEFAD), $18(1), 523-538$.

Sahin., C. (2018). Social media addiction scale - student form: The reliability and validity study. Turkish Online Journal of Educational Technology, 17(1), 169-182. 
Stankovska, G., Angelkovska, S., \& Grncarovska, S. P. (2016). Social networks use, loneliness and academic performance among university students. Paper presented at the Education Provision to Every One: Comparing Perspectives from Around the World BCES Conference Books.

Suganuma, Y., Okuno, J. i., Heslop, D., Roberts, A. P., Yamazaki, T., \& Yokoyama, Y. (2011). Post-depositional remanent magnetization lock-in for marine sediments deduced from $10 B e$ and paleomagnetic records through the Matuyama-Brunhes boundary. Earth and Planetary Science Letters, 31 1(1-2), 39-52.Available at: https://doi.org/10.1016/j.epsl.2011.08.038.

Tulu, D. T. (2017). Should online social Medias (OSMs) be banned at work? The impact of social Medias on employee productivity in Ambo University, a case study. Research in International Business and Finance, 42, 1096-1102.Available at: https://doi.org/10.1016/j.ribaf.2017.07.044.

Turel, O., Brevers, D., \& Bechara, A. (2018). Time distortion when users at-risk for social media addiction engage in non-social media tasks. Journal of Psychiatric Research, 97, 84-88.Available at: https://doi.org/10.1016/j.jpsychires.2017.11.014.

Tutgun-Ünal, A. (2015). Social media addiction: A research on university students. Marmara University Institute of Social Sciences Journalism Department, Department of Informatics Doctorate Thesis.

Ünver, O., \& Köse, H. (2020). Social media use of athletes, Multidisciplinary studies in sports sciences, (Ed: Gökmen Özen \& Özdemir Atar) (pp. 379-391). İstanbul,Turkiye: Efe Academy.

Vural, Z. A., \& Bat, M. (2010). Social media as a new communication environment: A research on Ege university faculty of communication. Journal of Tasar University, 20(5), 3348-3382.

Yamak, B., \& İmamoğlu, O. (2019). The beck hopelessness level according to behavior change stages in University Ondokuz Mayis students. Turkish Studies Educational Sciences, 14(3), 937-947.

Yamak, B., İmamoğlu, O., \& Çebi, M. (2016). The effects of the physical fitness levels of adolescents on body image, self-concept and stress levels. The Journal of Academic Social Science, 4(34), 191-201. 